\title{
Kinesin-Like Protein KIF2C
}

National Cancer Institute

\section{Source}

National Cancer Institute. Kinesin-Like Protein KIF2C. NCI Thesaurus. Code C104358.

Kinesin-like protein KIF2C (725 aa, $\sim 81 \mathrm{kDa}$ ) is encoded by the human KIF2C gene. This protein is involved in tubulin depolymerization. 